\title{
Participation at the Firm Level in the Transformation Process (Three blank slips of paper and a pigeon feather)
}

\author{
Csaba Makó and Agnes Simonyi
}

\section{Introduction}

The concept of participation has broadened in the past twenty years. Debate on the highly diversified forms of autonomy, cooperation and control within work organizations has enriched the sociological approach to participation after the initial and often simplified concepts of direct employee participation in decision-making. These advances oblige us to pay careful attention to new developments in the labour process, not just to test achievements in already-known dimensions and to measure results according to already-accepted theories of employee participation. In radically changing social situations, sociologists face a more difficult - but also more challenging - task, not only in confronting the new reality with existing paradigms but in identifying emerging phenomena or fresh combinations of former and recent features of social development.

In the late 1980s and early 1990s, in Central and Eastern Europe, there were widespread illusions as to the prospects of labour relations and the new role of employees and their interest associations. The international, economic and social conditions of the real processes of social transformation in these countries, however, framed events differently. The new institutions of labour relations and social cooperation displayed unexpected patterns, and social scientists are now seeking to understand the motives and intentions of the social partners within the transformation process. Since the social and economic context of the current transformation process varies from country to country in this region, very different strategies and practices of institution-building, combined with national and local traditions of interest representation and participation, are creating a rich variety of labour relations. The theme of this paper - namely participation is an integrated part of the complex system of labour relations. But this integration, in its form, contents and importance has never been homogeneous in the countries of this region and it has always exhibited obvious system-specific characteristics. 


\section{The Role of Participation in the Labour Relations System}

In principle, the following institutions - each of which has its own social and political weight - constitute elements of the autonomous system of labour relations (Héthy, 1991):

- The system of national-level tri-(bi)partite negotiations (In Hungary the National Council of Reconciliation of Interests, NCRI, was established as early as 1988).

- The system of collective bargaining between autonomous partners. Given the lack of autonomy of the partners, the earlier firm-level system of agreements cannot be considered to be collective bargaining, although it ensured a certain degree of consensus between management and employees, both of which, however, had dependent status.

- The institution of collective labour action, which was non-existent in these countries, with the exception of Poland and Hungary, until 1989-90.

- Employee participation took various forms in the region. One version was the system of union representatives (as in the former Soviet Union); another was so-called 'direct participation' (like the self-management system in ex-Yugoslavia, or the Enterprise Councils which have functioned in Hungary since the mid 1980s). A third version was based on the increased autonomy of employees and their groups in work organizations (considered as independent actors in firms' internal labour markets), examples being the economic working associations -"VGMK"- in Hungary or the autonomous work brigades of Bulgaria in the $1980 \mathrm{~s}$. Naturally, these three versions of employee participation could also coexist, thereby creating special mixes.

All four institutions of labour relations listed above have a rationale and traditions which have influenced the functioning of the others. In certain periods, one institution has substituted for others or they have exchanged roles. For instance, the already substantial experience of tripartite negotiations has established norms for firm-level agreements in the absence of a well-developed system of collective bargaining. Or direct participation by employees in management may have partially replaced the still immature practice of labour action.

The autonomous system of labour relations has its political, legal and economic dimensions. National level negotiations comprise mechanisms which connect labour relations to political decision-making (government, unions, employers and union organizations, parliament, etc.). The economic and social structures underpinning the substantive rules of the various markets are expressed in the system of collective bargaining. The legal regulation of collective bar- 
gaining and labour disputes link the system of labour relations to the national system of jurisdiction.

Participation is a field in which individual as well as collective action, economic interests as well as self-realization, interweave. The seemingly 'softest' institutions of labour relations comprise a scenario in which employees react to ongoing technological, organizational, financial and labour market developments in their sector. In this sphere, the patterns of everyday workplace cooperation are constantly reformulated in the light of new individual and collective experiences. In influencing the decision-making process, in solving technical or organizational problems, in manipulating human relations, and in expressing interests, people not only construct their working life but create the basic conditions for social, economic and cultural reproduction. None of the economic reforms of the past decade could have succeeded if they had not taken account of this fact; and nor can the current transformation process ignore the complex web of relations among these micro-worlds.

\section{The Forms and Dimensions of Participation}

Employees may participate in their firm's decisions at different levels: they may express their opinions and interests at the level of their immediate workplace, workshop or office, and at higher managerial levels. This dimension of participation corresponds to a decision-making system which may or may not provide room for differing degrees of employee involvement in a firm's affairs.

Another dimension of participation is the closeness of involvement in the firms' managerial and decision-making system, ranging from the exchange of information, through official respect for the employees' opinions in decisions, to codetermination. These types of involvement may be officially regulated by laws and agreements or by social practice and traditions. These latter may sometimes be more influential than legal regulations, although their combined effects vary from country to country, and also according to the context of managerial systems or of local, branch, firm-level practices. From the employees' point of view, the intensity of their involvement may be characterized by other categories as well. Occasional participation or the expression of opinions in support of colleagues, unions or managers represent an intensity of involvement at a lower level than regular contributions in the form of organized action or the acceptance of official responsibilities (membership of works councils, union representation) within the decision-making process.

As regards the aims of participation, a distinction is drawn between problems relating to working conditions and strategic issues. A similar approach, though 
one more differentiated in its sociological character, is adopted when task- and power-oriented participation are distinguished.

All the above-listed dimensions may take the form of direct or indirect (representative) participation. Indirect participation is exercised through various interest-representing associations (unions, works' or enterprise councils, bodies supervising pension and health funds, etc.). Direct participation takes a wide variety of forms in the world. There are the forums and institutions of communication between management and employees, ranging from quality circles to regular workshop conferences on production issues, innovations or on working conditions. Since the 1970s, important initiatives have been undertaken in this area following the new human resource management approach. Direct employee participation may take place through such organizational arrangements as 'assembly cells', 'working islands', 'modules', internal subcontracting groups (like the Hungarian VGMK in the 1980s), where employees shape their everyday working practices and, in the longer term, the patterns of cooperation and power relations within the labour process.

Property partnership and financial engagement in the maintenance of employment is regarded as a special form of employee participation. The American ESOP schemes are the most well-known examples. But the various forms of MBO, the Hungarian MRP (a version of the American model), various company stock ownership systems, the East Central European coupon-based employee ownership system, or other direct forms of property-sharing, also belong to this category of participation. The objectives behind the creation of these types of employee participation vary from the economic to the social. Whatever the intentions may be, the safeguarding of employment, the broadening of financial resources, the creation of closer employee identification with the firm, and property-sharing can be achieved in very different organizational and managerial settings. Day-to-day participation practices within such firms do not automatically increase with financial participation by their employees.

\section{The Role and Importance of Participation in the Hungarian Labour Relations System}

In Hungary, the various components of the labour relations system have developed unevenly over past decades. In the previous political context, ideological and political limits were set on the development of the first three of the abovementioned components. All three areas - the creation of national level tri- or bipartite negotiations and the institutionalization of collective bargaining, as well as of labour disputes - were not tolerated by the still monolithic political 
system. However, there was always the need to create social consensus in the workplace level which favoured the development of various forms of employee participation in Hungary. The motives were very different, ranging from management interest in cooperation with the rank-and-file, through the adaptation and diffusion of new managerial techniques, the ideologically motivated endeavour to humanize the workplace with especial emphasis on identification with the firm, to politically motivated attempts to introduce so-called self-management schemes in order to counterbalance growing managerial power. (These last-mentioned motives were especially visible in the 1980 s as the political forces attempted to maintain control over the emerging technocrats and union bureaucracies who, often in coalition with managers, successfully influenced redistribution processes against the centralizing efforts of the national political and economic actors.) These concepts, the desire to realize them, and the life-span of the different forms of participation, were subject to interaction among different social forces at the firm and national level.

Both forms of employee participation - the direct and the representative (indirect) - were widespread in the Hungarian system. The most important direct forms were experimentation with autonomous working units, group-level decisions on wage distribution, group-based cost-saving centres, internal subcontracting systems, and the widespread and highly publicized working associations (VGMK) of the 1980s. The growing role of union representation - as expressed through the various shop steward and firm-level union committees after the mid-1970s, together with the creation of enterprise councils as self-governing bodies in the second half of the 1980 s - was the most significant development in indirect participation. Having gradually obtained their participation and bargaining rights, the unions were anxious to see how other direct forms of employee participation and non-union representation could be implemented. They were afraid of losing their newly-acquired functions (of the 1970s) in employee representation, which was a well-known component of labour-relations systems in the industrialized countries. In Hungary, the unions' position was more problematic, since they were still in a politically dependent position until 1989, and they felt threatened after the 1970 s by non-union-controlled representation and direct participative forms, and by new managerial techniques to create direct channels of communication with the employees.

Research has shown that employee participation was a key element in Hungarian labour relations after the 1970 s. In its different forms it partially substituted for the autonomous institution of collective bargaining and labour disputes, and, together with informal mechanisms of interest conciliation, helped to stabilize the work process while creating enduring cooperation between the partners at the firm level. (The tight labour market situation and the organizational problems generated by the shortage economy strengthened the informal power position of the work groups who played a crucial role in solving them.) 
Increased opportunities for firm-level participation after the 1970s enabled certain employee groups to accumulate important social skills in the evaluation and manipulation of social and organizational situations, in negotiation with different social partners, and in the elaboration of overviews of enterprises and their environment. These experiences directed attention to the limits of participation, and they highlighted the missing elements of the labour relations system which were hindering the expansion and more efficient use of firm-level participative schemes.

\section{Changes in the Role and Place of Participation within the Labour Relations System since 1989}

Since 1988/89, in Hungary - somewhat earlier than political transformation itself - the system of labour relations has been reformed. Labour relations have developed into an autonomous system as the social partners, employers and employees and their interest-representing organizations, have gained independence from other political and economic organizations. The roles of the main actors in the labour relations system have been clarified, and they have acquired the right to negotiate with each other as well as with the government. Legislation (the new Labour Code, the Employment Act, etc.) has regulated their sphere of action and the different institutions of negotiating, bargaining and the collective solution of labour disputes. Recognition of the social partners' independence has given rise to the pluralization of the competing interest-representing organizations, so that new unions and employer organizations have been born. At the national level, a Council of Interest Reconciliation was created in 1988 to negotiate and agree on wage increases and social and employment issues prior to parliamentary debate.

These innovations in the labour relations system have been especially important in a situation of overall changes in the Hungarian economy. The comprehensive transformation of property relations, the privatization of public firms, together with the emerging new private sector, the decentralization of many of the former large organizations and the profound economic recession - these have been the main factors of economic transformation. In circumstances of unstable economic conditions and the huge social costs of transformation met by large groups, the above-described new elements in labour relations helped to maintain stability and sometimes even to resolve critical situations of unrest.

At the same time, firm-level participation seemed to lose its importance. There were (and still are) certain commentators who expected firm-level negotiations and bargaining (formal or informal) to diminish in importance under pressure 
from the new phenomenon of a high level of employment. Others supposed that private property and capitalist management would 'import' the well-known methods of firm-level negotiations which 'manufactured consensus'.

Apart from these assumptions (that I shall attempt to refute later on), the place of participation in the Hungarian labour relations system has certainly changed. It has lost its political and ideological significance (local employeremployee conflicts can hardly be transposed into basic social contradictions), and its functions with regard to to firm-level issues have became more circumscribed. In the meantime, the social and political positions of the partners have been re-established at the firm level due to various factors: the appearance of direct private property, the definitive disappearance of the 'mythologies' of work and the 'class approach', declining production because of the deepening recession, and the new institutions and legal measures enabling decisions or protest to be influenced at the firm level. However, it would be an over-simplification of the situation to state that these new rights have been acquired by employees in a historical period in which they have lost their real bargaining strength under pressure from the labour market and the recession.

Employee groups in a strong position within firms can still be found, despite dismissals and unemployment. Even with increased unemployment, productivity has fallen, demonstrating the survival of low requirements. The high social costs of transformation and the lowering of living standards have been tolerated, and the strike rate has been low in the past few years. Some strikes have been desperate revolts against the 'non-cooperative' management of workers in marginal sectors and positions, while others have been mounted by powerful employee groups in order to improve their pay and working conditions.

A view widely accepted among labour relations experts is that, in periods of recession, when unemployment increases the number of strikes diminishes. This is taken to be a sign of the weak bargaining positions of employees and their unions. In this respect, Hungary seems to be no exception. While in the 1980s there were widespread fears among Hungarian (and other Central East European) political and social scientists that a fall in living standards accompanied by a retreat from full employment would lead to social unrest, this has not been the case in these first years of the transformation period. The number of strikes, participants in them and the total of days lost through strikes, have all remained low in Hungary, thereby testifying to the validity of the above 'rule' on the lower level of open and manifest conflict circumstantiated by formally weakened bargaining positions. At the same time, doubts may be raised concerning the differentiated bargaining positions of workers still in employment. In Hungary, where the majority of the jobless are long-term unemployed and hundreds of thousands are in casual employment, these facts show that those who managed to keep their jobs in the first waves of lay-offs and workplace closures, are considered necessary for the stabilization and possible recovery of their firms. 
I now briefly describe a case which shows that there is no direct relationship between a given labour market situation and the employees' bargaining position.

\section{A Managerial Initiative Rejected}

The ' $D$ ' Co. Ltd. was created at the beginning of 1992 as a joint venture with two-thirds Hungarian and one-third foreign ownership. Half of the company's products are sold on international markets. The foreign proprietors took over key positions in management and launched a new human resources strategy for the firm. Together with the Hungarian representative of the management, they were convinced that it was sufficient to give the blue-collar workers somewhat higher wages and better working conditions compared to the firms operating in the local labour market and management could rely on a satisfied workforce. When establishing the joint venture, the mixed management signed an agreement with the local union which guaranteed employment and the level of the firm's social benefits.

The principal objective of the new management was to maintain and increase the company's market share through improved quality. For this purpose they introduced a 'knowledge centred' incentive system which replaced the former one in which low-skilled workers received better wages than their highly qualified colleagues. This innovation was linked with the introduction of the new 'Quality Insurance System', which required the support of the workers, of their unions, of lower level supervisors, and of middle level managers.

Despite the efforts of the new management, higher wages, better working conditions and stable employment, there was no significant improvement in productivity, in product quality, or in the level of morale among the workers and within the firm as a whole. The following factors were apparently responsible for low morale. There were exaggerated expectations among the company's shopfloor workers of radical wage increases; indeed, that Hungarian wages would soon reach the Austrian level. This 'dream' was fuelled during preparatory negotiations of the planned joint venture by some of the Hungarian managers probably in order to ensure the workers' support. Austrian wages, in fact, are extremely high - six to ten times higher - when linked with productivity and product quality, but otherwise 'only' one and a half or two times higher than Hungarian wages. The other reasons for low morale lay outside the blue-collar worker's community and within management. After the creation of " $D$ " Co. Ltd., the new top management of the Hungarian-Austrian joint venture introduced a management style based on the 'autocratic' version. From a technical 
point of view, these decisions were well prepared and elaborated. But they lacked the participation not only of the workers and unions but also of the middle managers, who had played an important role in the decision-making process of the former publicly-owned firm but were now entirely excluded from the decisions taken by top management. Thus, this important sector of management could not and did not identify with the firm's management decisions. In this type of decision-making system, both blue collar workers and managers are merely 'executors', they are not 'co-creators' of the firm's policy aimed at changing the incentive system, quality assurance, and to introduce a new practice of manpower use. The management of " $D$ " Co. Ltd. first made an appropriate diagnosis: they thought that the lack of cooperation between workers and managers was the result of communication difficulties. To overcome this human relations problem, the management introduced an open policy initiative by asking the workers to inform them about their interests and the topics that they wished to read about in the company's newspaper. In order to collect the workers' opinions on managerial initiatives, "sealed mail boxes" were placed in each workshop in "D" Co. Ltd. Two months later, before publication of the next issue of the company's newspaper, the manager responsible for communication between management and the rank-and-file attempted to gather the workers' opinions. But the overall results of the campaign were as follows: "Three blank slips of paper and a pigeon feather". After this complete failure of its initiative to improve communication and open dialogue with the workers, the management realized that, within its ranks, the middle managers were more on the side of the workers than of top management. The trade-union plant-level organization pursued a policy of 'confrontation' with the top management's initiatives and, in this respect, the middle managers supported union action against management. In the absence of overall consensus between rank-and-file, middle managers and top management, the employees refused a minor offer by the management for participation and applied pressure to influence wider issues of working conditions. If one examines not only certain isolated phenomena of participation or non-participation (refusal to participate) but also the dynamics of "everyday workplace events" and continuous changes in the relationships between the partners, one finds that employees realized their interests through both open and hidden forms of participation.

After the failure of the above-mentioned managerial campaign to improve communication with the workforce, shop-floor workers and middle managers achieved success in various important areas - for instance, by signing the first Collective Agreement of June 1994. The top managers - or key figures in the company's executive management - were forced to recognize the necessity of building the social consensus of their partners. Establishing stable agreement with the workers and the unions would identify not only the interest- and powerrelations among the workers and between the workers and the trade union but 
also within the management. With regard to this latter aspect, it was crucial to realize that the 'malaise' of the middle managers was due their lack of participation in the firm's decision-making process. The initial diagnosis identified the tensions between managers and workers as psychological in character (misunderstandings, difficulties of communication, etc.). However, after a one-and-ahalf year 'learning process', management discovered the true nature of the problem: that is, the key role of interests and power relations. It became obvious that the 'core workers' (and the union leaders) or the middle managers would not voluntarily practice self-restraint or give up their 'strong positions' in the decision-making system created in the former state company. Within this social context, the rejection of the management's proposed form of participation - collection of workers' suggestions and their publication in the company newspaper is understandable. The different forms of employee participation (the voicing of opinions in the newspaper, work's council since 1993, etc.) are an important component of firm-level labour relations. However, these participatory instruments cannot substitute for collective bargaining or social consensus based on the concertation of interests and power among the social partners. In this regard, it is worth noting that collective bargaining and labour disputes are the best known system of short-term interest conciliation between the employer and employees. The role and function of participation are also linked to interest relations and power relations, but from a long-term rather than short-term perspective (Gábor Füredi (1994).

\section{Combining 'Voice' and 'Loyalty'}

In a situation of profound crisis between the social partners in a firm, participation can substitute - temporarily - for collective bargaining. In the case of ' $\mathrm{C}$ ' Co. Ltd., which operated in the textiles industry, a seemingly paradoxical situation has been described: resistence and strong protest combined with cooperative participation. (Orolin, 1994)

' $C$ ' Co.Ltd. was established in the autumn of 1990 , with $50 \%$ Hungarian and $50 \%$ Italian capital. The objective of Italians was both to acquire markets and to gain long-term profit based on low wages. (At present the average wage in ' $\mathrm{C}$ ' Co. Ltd. is a little more than one-eighth of the average in the Italian plants of the foreign investors.) The priorities of the Italian owners can be summed up as follows: order, discipline, quality and profit. Within an extremely short period of time, the workforce was cut to $30 \%$. Before privatization, 1000 workers produced 80,000 metres per day of different textiles. In the new Italian-Hungarian firm, this quantity was produced in a month by the 300 workers that remained. 
In parallel with this decline in employment and production, the influence of the former trade union was eroded. The changes in the ownership structure resulted not only in an increased intensity of work and slow wage growth increase but also, surprisingly, in badly organized work and worsening working conditions. Preparation for the privatization of the former state textile (weaving mill) company was carried out in a "climate of secrecy": nobody was informed about the privatization plan. The employees therefore thought that everything was against them. In everyday factory life, the 'Italian trainers' treated the Hungarian textile workers as 'third rate workers' and showed no respect for them: even joking and chatting were prohibited during working hours. After two and a half years of unsuccessful attempts by the workers to reach collective agreement on job classification and wage increases - in an industry in which male workers were paid the lowest industrial wage - the workers staged a 'warning strike' in October 1993, and later a longer strike in December of the same year. (The degree of support for the strike was $90 \%$ in the plant situated in the capital, and $100 \%$ in the plant operating in a regional centre.) Despite the strikes, the Italian owners who during the two and a half years had increased their property share and had become the dominant owner - finally agreed to a $12 \%$ basic wage increase and an $8 \%$ quality bonus (premium), but they did not sign the collective agreement.

To understand the economic performance of "C" Co. Ltd. one must bear in mind its huge indebtedness (100 million Ft) due to the shrinking market. In this situation, the very survival of the firm was at stake. The workers were strongly aware of the firm's imminent bankruptcy: for them, the real threat was not the signing of the collective agreement but the survival of the firm and hence the saving of their jobs. The situation was aggravated by the constant violation of the Hungarian labour code by the Italian director - who was unaware of Hungarian law regulating labour relations. Even in these circumstances of conflictual labour relations, the workers participating in the strike expressed their commitment to and strong identification with the firm. This emerges clearly on reading extracts from the 'memo' drawn up by the Worker's Assembly during the warning strike:

\footnotetext{
"Beyond the disorganization of work, there are numerous deficiencies and mistakes in the technological instructions for which the worker's collective cannot take responsibility. Employees, guided by professional self-esteem and by the risk of losing their jobs in the case of plant closure due to bankruptcy, tried to warn the decision-makers of the Co. Ltd. in time to avoid damage caused by the inappropriate technological instructions. The worker's assembly cannot accept and rejects the Italian organizers' often abusive behaviour towards the workers ...” (Orolin, 1994: p. ).
}

Hence workers' participation in this case has a twofold character. On the one hand there is strong protest which even takes the form of strikes for agreement to be reached on the most important issues of working conditions, employment 
and wages. On the other, workers constantly participate in solving the technological and organizational difficulties of the plant.

Those forms of participation consisting of strong protest or a rejection of managerial initiatives, and the forceful representation of employee interests, may give rise to formal collective labour disputes. With reference to alreadymentioned elements of Hungarian labour relations, we may say that employee participation may either provoke or prevent the escalation of labour disputes into strikes. The distinctive feature of Hungarian labour relations is the low level of strike activity compared with the other countries undergoing transformation in Central and Eastern Europe.

According to the research report compiled by the Phare Project Fact Finding Committee in 1993, which examined different forms of participation and compared views and interests, in many cases the threat of strike action leads to the settlement of conflicts. In $30 \%$ of cases, formal strike calls were not followed by strikes, and peaceful solutions were found instead. In particular, broader and branch-wide strikes (for instance in the railway or the electricity generating sectors) were prevented by agreements reached after the strike had been called. As collective labour disputes were being prepared, the social partners conducted intensive negotiation, either directly or through their representatives, in order to establish the pre-conditions for further cooperation. In 1993, eleven branchlevel wage agreements were reached, covering $5 \%$ of all the employees. Altogether, around $16 \%$ of the labour force was affected by such agreements (Berki, 1994).

In some of the multinationals to have established plants in Hungary (in the form of 'green field' investments), different forms of employees resistance have led to important wage agreements and to the establishment of the first smaller local unions, thereby emphasising the importance of the works' councils. The labour relations system of the multinationals operating in Hungary modulates between their national traditions, international contexts and Hungarian development (Neuman, 1993).

\section{Changes Towards a Three-dimensional System of Participation}

As a new element in the changing labour relations system since 1993, especial mention should be made of the works' councils. These are institutions which provide representation for the entire workforce; and they have had several predecessors in Hungary: in 1918-19, between 1945 and 1948, in 1956, and in different revolutionary periods as institutions ensuring workers' control when 
managerial influence has weakened. Despite obvious differences in social, economic and historical circumstances, several common institutional features can be discerned in their reappearance and functioning:

- Workers' councils were created in revolutionary situations when the traditional institutions of political democracy were paralysed, and when radical changes in property relations had created a vacuum and instability in management.

- This form of workers' self-management was designed to integrate the contradictory roles of employers and employees. The intention was to defend the employees' interests (as with any traditional union) while taking over managerial responsibilities (in organizing production). In 1919, for example, workers' councils were responsible for labour discipline, defence of socialized property, and production control.

- These councils have never restricted their action to the firm level, but seek to establish ties both horizontally and vertically in order to gain political control over the national economy: partly because of their ambitious and contradictory aims and partly in order to stabilize the political, social and managerial institutions, i.e. parliament, unions, private and public property (Varga, 1989).

In 1992, the Labour Code prescribed the creation of works' councils as obligatory in all firms in order to ensure employee participation in work-related decisions. Works' councils were to be elected in firms with more than fifty employees - and works' delegates in smaller firms with more than fifteen employees by secret ballot for a three-year period. The candidates were to be nominated by the unions or other groups of employees. These councils have the following rights:

- co-determination of the firm's social welfare decisions;

- the expression of employees' opinions on managerial decisions concerning reorganization, privatization, the use of human resources, vocational training and retraining, new working methods, and so on;

- information provided at least twice a year on the firm's economic situation, on investments, wages, liquidity, etc. At the same time, these councils cannot organize and support strikes.

The institution of works' councils represents a radical break with the past when the trade union's function of employee interest representation and participation were confused. The new Labour Code separates the main function of the unions (interest-bargaining) from participation by employees. According to the Labour Code: " Participative rights are exercised in the employees' name by works' 
council or works' delegates elected by them." (Labour Code, 1992: chap. IV. par. 42).

Besides participation in interest representation and bargaining through the unions, the works' councils in their present form can be regarded as a second institution for employee participation. The mandatory system has certain similarities to those in other countries (like Germany or Austria) with a so-called 'dual system' of labour relations. It is expected to develop social norms and rules of the game for long-term conflict resolution between the social partners at the firm level. The outcome of these rules may foster cooperation between employers and employees and among their different groups.

Owing to the short life of the works' councils, it would be premature to evaluate their activity. The first ballot in 1993 redefined the representativeness of the different union confederations. Of the eight trade union federations, MSZOSZ received $71 \%$, the Autonomous Unions $18 \%$, and the Democratic League of Independent Unions $6 \%$, of votes during the works' councils elections. There are signs that trade unions consider the works' councils to be their rivals in influencing decision-making at the firm level. This is due to the as yet incomplete divison of labour between the two institutions which would formally separate bargaining and cooperation.

Mention should finally be made of a new element in employee participation as a social product of spreading innovative managerial techniques in the field of human resources. In the vacuum of labour relations immediately after political trasformation, the need for everyday communication and problem-solving has over-ridden direct relations between management and employees' groups (see the above case of the Austro-Hungarian firm). Moreover, the transfer of Western managerial skills and systems is one of the most visible and urgent challenges faced by the Hungarian economic elite, given the growing influence of Western and multinational firms. Various forms of teamwork, 'lean' and 'flatter' organizations, the establishment of more 'heterarchic relations' within organizations, the reorganization of firms' newspapers and bulletins, group discussions, are all on the list of new managerial initiatives. (Makó Cs. - Novoszáth P. 1994.)

Privatization, productive decentralization, the crisis of the redistributive mechanisms, the diminishing possibilities of 'concession policy', the pluralization of employee and employer organizations - all these individually and collectively constitute a challenge for Hungarian labour relations. Not by chance, the social partners have been pressing for a 'social pact' since 1990 .

At the national level, there is a strong need to stabilize social relations through centralized agreements. But at the firm level, despite the relatively high unemployment rate and economic recession, high quality performance, problem-solving, adaptability, cannot be obtained through central agreements. Cooperation between employers and different employee groups is based on economically 
motivated collaboration, not on institutionalized and/or ideologically motivated social obligations. Even without public intervention, this leads to the "microcooperativism" (Streeck, 1991) constituted by the rational self-interest of the social partners in employment, wages, skilling, working conditions. This tendency, which has been described in the highly developed countries during the past decade, can be identified in some spheres of the Hungarian economy as well. Thus, within the Hungarian system of labour relations, highly heterogenous firm-level configurations resulting from the multiform presence of participation are becoming of crucial importance. Unified and centralized models of labour relations are important to establish a stable political background, and so are norms regulating the relationship between the social partners, but their role in orienting firm-level labour relations should not be overestimated.

\section{References}

Berki, E. (1994): Bérmegállapodások, 1993, Munkaügyi Szemle, XXXVIII. Évf., Január Burawoy, M., Lukács, J. (1992): The Radiant Past, (Ideology and Reality in Hungary's Road to Capitalism). Chicago: The University of Chicago Press.

Füredi, G. (1994): "New Requirements for Human Resource Management in the Joint-Ventures Firm: the Case of the DWA", in: Makó-Novoszáth (eds.): Convergence vs. Divergence: the Case of the Corporate Culture. Budapest:Com and Con Co. Ltd. - Center for Social Conflict Research HAS.

Héthy, L. (1991): Hungary's New (Emerging) Industrial Relations System, Trends and Dilemmas. Budapest: Institute of Labour, Ministry of Labour.

Ishikawa, A. (1992): "Patterns of Work Identity in the Firm and plant: An East-West Comparison", in Széll (ed.): Labour Relations in Transition in Eastern Europe. New York: Walter de Gruyter

Makó, Cs., Simonyi, A. (1992): "Social Spaces and Acting Society", in Széll (ed.): Labour Relations in Transition in Eastern Europe. New York: Walter de Gruyter, pp. 60-76.

Makó, Cs. (1992): From State Corporatism to Divided Unionism? Project on "Industrial Relations and Trade Unions in Former Socialist Countries". Vienna: Institute for Advanced Studies.

Neumann, L. (1993): "The Hungarian Suzuki". Budapest: Institute of Labour, Paper prepared to the OECD Seminar.

Orolin, Zs. (1994): A Cantoni Kft munkaügyik kapcsolatainak alakulása: 1990-1994. Budapest: MÜM Munkaügyi Kutat-Intézet.

Poór, J. (1994): Towards the Western HRM Practices in Local Subsidiaries of MNCS in the Former Socialist Economies, 9th Workshop on Strategic Human Resource Management - EIASM, St.Gallen, 3-4 March.

Simonyi, A. (1994): Foglalkoztatás és munkavégzés dolgozói tulajdon-ban. Budapest: OTKA Kutatási Jelentés, Május.

Streeck, W. (1988): Editorial Introduction, in Economic and Industrial Democracy, vol. 3, no. 3. August, pp. 307-8.

Varga, L. (1990): "Munkástanácsok Magyarországon: 1918/19-1956”, in Makó-Nemuman (eds.): $A$ munkásutonómia kiterjesztésének lehetségei, Budapest: MTA Szociológiai Kutató Intézet.

Vince, P. (1993): Stages of State Involvement: Dilemmas and Turning Points for Privatization in Hungary. Budapest: Kopint-Datorg. 